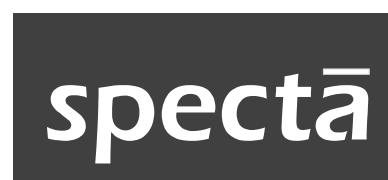

Journal of Photography, Arts, and Media

\section{FILM NEGATIF SEBAGAI MEDIA AKHIR: KONSTRUKSI BENTUK DAN MONTASE FILM NEGATIF DALAM FOTOGRAFI SENI}

\author{
Fachrozi Amri
}

Fakultas Ilmu Dakwah dan Komunikasi, UIN SUSKA RIAU

Surel: roziamri@gmail.com

\begin{abstract}
Abstrak
Karya fotografi dalam penciptaan ini merupakan upaya untuk memanfaatkan teknologi yang sudah ditinggalkan. Pemanfaatan media fotografi analog sebagai salah satu alternatif baru yang ditawarkan dalam riset penciptaan ini yaitu menghadirkan kembali media film negatif sebagai sarana media akhir tanpa melalui proses cetak positif. Butuh penanganan khusus dalam membuat karya ini, artinya ada usaha-usaha menembus batas atau menawarkan kemungkinan lain dari kebiasaan fotografi pada umumnya, yang tidak banyak dilakukan oleh fotografer. Karya diciptakan tidak hanya sekedar menggunakan media film negatif saja, melainkan memuat puluhan bahkan ratusan lembaran film negatif yang saling terhubung secara sintetis. Penyusunan lembar-lembar tersebut (nomor 1-36), adalah salah satu upaya untuk menghubungan antara peran kreasi, desain, konstruksi dan ketelitian. Pendekatan karya ini hadir dengan mengkonstruksi bentuk, yang juga dikerjakan oleh seniman asal Inggris yaitu David Hockney (80). Dalam karya yang dikerjakannya, Hockney mengkonstruksi ulang potong-potongan bentuk, menggunakan cetakan polaroidnya, lalu menggabungkannya kembali menjadi bentuk yang telihat distorsi. Sifat fisik film negatif terbuat dari bahan plastik celuloid transparan, maka dibutuhkan cahaya tambahan, dengan cara menyatukan antara lembaran negatif ke lembaran negatif lainnya, sehingga dapat terlihat utuh kontruksi bentuknya.
\end{abstract}

Kata Kunci: film negatif, kontruksi, fotografi

\begin{abstract}
Negative Film as the Final Medium: Construction of Form and Montage of Negative Film in Art Photography. Photography artwork is one of aims in utilizing the long abandoned technology and utilizing the analog photography as one of the new alternatives in this research and creation. Negative film is brought back as final medium without printing the positive. Extra care is needed in creating this artwork, means some efforts are beyond limit or means that it offers a lot of possibilities from the ordinary habits of photography, which are not commonly done by photographers. The artworks are not only created using negative film, but also contains of hundreds of sheets of negative film which are connected synthetically. Sheet number 1-36 are arranged to connect the creation, design, construction, and thoroughness. In approaching the artworks, form reconstruction is done as once conducted by David Hockney (80). He reconstructed pieces of shapes, using his Polaroid mold, and rejoined them together in distorted form. Since negative film made of transparent celluloid, additional lighting is needed so that the rejoining step from one sheet of frame to another could be seen intact in its whole construction.
\end{abstract}

Keywords: negative film, construction, photography 


\section{PENDAHULUAN}

Aktifitas kesenian, khususnya di dunia fotografi kini sangat dipengaruhi oleh produkproduk digital, dan teknologi analog sudah mulai dilupakan. Produk digital, sebut saja kamera digital, dengan perangkat lunaknya, seperti photoshop serta software digital lainnya. Teknologi digital sudah merambah kehal-hal kecil seperti pengunaan handphone, yang mana sudah didukung dengan perangkat lunak seperti fitur kamera. Hal ini telah memberikan nilai kontribusi bagi masyarakat fotografi pada umumnya.

Siapa saja sudah bisa menggunakan fotografi sebagai sarana dokumentasi atau dijadikan alat menyalurkan hobi serta membuat karya seni, menjadi kreator di bidang fotografi yang serba digital sangat mudah dicapai, terlebih bila fotografer juga dilengkapi pengetahuan yang cukup tentang fotografi. Dalam hal ini, terlihat ada peluang untuk membuat karya yang sudah mulai ditinggalkan seperti membuat karya seni fotografi menggunakan perangkat analog, dalam pengunaan teknologi analog, baik dari segi peralatan (kamera) atau media rekamnya (film negatif). Celah ini yang ingin dimanfaatkan untuk menghadirkan suatu karya yang unik, dalam pengunaan film negatif sebagai mediumnya, di tengah masyarakat yang sangat konsumtif terhadap pengunaan teknologi digital.

Dalam tulisan ini akan diuraikan sebab dan akibat terwujudnya kekaryaan, yang dilatarbelakangi hal yang tersebut di atas. Di antaranya adalah memenuhi prasyarat akademis dan pertangungjawaban untuk membuat karya dengan menghadirkan karya fotografi bermediakan film negatif. Dengan teknik kontruksi dan penyusunan serta penggabungan sejumlah imaji (montase) menggunakan film negatif, sehinga terbentuk imaji baru. Artinya, karya ini yang akan dihadirkan hanya menggunakan film negatif saja tanpa dicetak di atas kertas, yang umumnya hasil akhir di fotografi adalah cetakannya (positif).

\section{Contact Sheet}

Dengan menggunakan contact sheet film negatif di karya akan dicoba untuk dinemukan pendekatan teori yang sudah dikemukakan sejumlah tokoh fotografi di antaranya contact sheet atau contact print menurut Hedgecoe (996: 185),

"Print that is the same size as the negative, made by sandwiching together the negative and the photographic paper when making the print. Finaly, the contact print is a lasting quick-reference record that you can store white the appropriate sheet of negatives for use. you can write notes about exposure times and other information on the contact print".

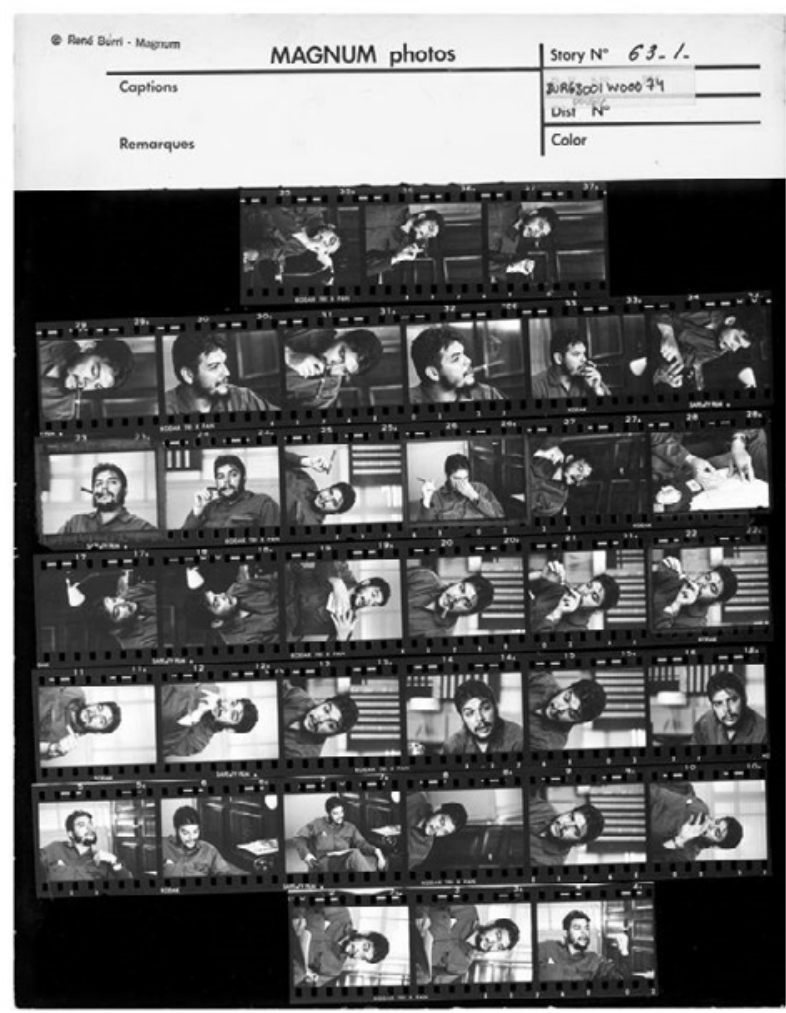

Gambar 1. () Rene Burri, Collection Magnum Photo. (1963CUBA). Ministry of Industry. Ernesto GUEVARA (Che), Argentinian politician, Minister of industry (1961-1965), arsip tahun 2015.

(Sumber: https://www.magnumphotos.com/theory and-practice/ magnum-contact-sheets/, diakses pada tanggal 25 November 2016, pukul $17.00 \mathrm{wib})$ 
Salah satu contoh contact sheet pada umumnya dibuat oleh fotografer (gambar 1), karya ini milik fotografer dokumenter, Rene Burri koleksi Magnum Photos. Contact sheet ini merupakan contoh cetakan umum dari teknik cetak tersebut, sebuah hasil bidikan fotografer yang dapat dilihat dan dipilih, sesuai dengan keinginan fotografer. Tampilan frame yang ada di contact print pada umumnya tidak dijadikan satu bentuk karya yang satu, tapi seperti jendela untuk melihat hasil yang ada di luar jendela bidik. Akan tetapi, bukan contact print tersebut yang akan dibuat kembali, melainkan penyusunan bentuk didalam teknik penyusunan lembaran negatif yang memiliki kesamaannya, walaupun film negatif yang disusun bukan untuk dicetak di atas ketas seperti yang telihat di karya tersebut.

\section{Konstruksi Bentuk}

Film negatif digunakan dengan mengkontruksi bentuk imajiner/ilusi lalu disusun sejumlah lembarannya menjadi sebuah bentuk yang dikonstuksi walaupun bentuk itu bukan berasal dari satu bentuk yang satu. Karya akan dibuat menggunakan sebuah metode konstruksi bentuk. Hal tersebut dapat diartikan sebagai membangun sebuah bentuk dari bentuk yang berbeda menjadi satu, kesatuan dari isi kesatuan. Ketika dilihat bentuk tampak sebagai tampilan sesuatu dari muatan penuh ruang, dari puluhan frame yang dihadirkan. Maka bentuk tidak selalu mewakili objek tunggalnya saja, melainkan dibaca secara keseluruhannya, bisa juga diartikan, ini merupakan sebuah konsep membentuk.

Ada dua hal yang dapat kita temui di karya nantinya yaitu bentuk sebagai suatu jenis bentuk tampak tertentu (dikenali), yang kedua akan terlihat bentuk sebagai keseluruhan jenis objek yang dihadirkan secara kesatuannya. Nantinya bentuk akan ditangkap oleh indera, dimulai dengan mempersepsinya, dengan menangkap ciri stukturalnya yang paling menonjol,apakah akan menyerupai suatu yang dikenali atau hanya pada tahap ilusi bentuk saja. Akan lebih baik dalam melihatnya jika mengabaikan detail objeknya, akan tetapi fokus melihat secara keseluruhan dari strukturnya yaitu bentuk utuhnya. Punctum atau element tersebut tidak akan terbaca bila utuh dari bentuk tidak dikenali. Akan tetapi dalam mengenali bentuk dalam karya ini, penikmat fotografi tidak mungkin akan mengabaikan detailnya, walau hal tersebut sangat terbatas dan sangat subjektif, tidak ada paksaannya dalam melihatnya.

Bentuk yang dimaksud ini juga disebut sebagai bentuk perseptual, yaitu bentuk yang dipengaruhi hal yang sangat melatarbelakanginya, apakah itu dari penglihatannya dan persepsinya. Hal senada juga diutarakan oleh Kenyowati, Embun dalam Disertasinya yang berjudul "Ilusi dalam Seni Visual". Bentuk perseptual merupakan hasil dari saling mempengaruhinya antara objek fisik, pencahayaan dan kondisi yang berlaku dari sistem syaraf penglihatan. Demikian juga setiap pengalaman visual melekat dalam konteks ruang dan waktu. Seperti tampilan objek dipengaruhi oleh objek di sekitarnya dalam ruang, demikian juga ia dipengaruhi oleh pandangan terdahulunya (Embun, 2009:98).

Dalam mengetengahkan karya seni dari media fotografi yang menggunakan teknik tersebut, akan memberikan pengertian tentang seni yang ingin diungkapkan secara luas, dengan merespon hal yang ada di kehidupan nyata atau tidak nyata (fantasi atau imajinasi). Merespon kembali peristiwa lewat wacana estetika yang lebih terbuka. Ketika pesanpesan pada karya foto telah dimengerti dan diresapi sebagai sebuah makna tertentu maka hal tersebut akan mengandung daya penyadaran dan daya pembelajaran. 
Seperti sebuah bangunan, yang mencoba mengambil peran untuk membangun sebuah imaji ke dalam karya fotografi. Maka, disusunlah bentuk satu dari berbagai macam objek yang dihadirkan secara berurutan, sehingga menghasilkan atau terlihat seperti sebuah bentuk yang dikenali atau sangat menyerupai bentuk-bentuk baru, apakah itu dilihat dari pencahayaannya, perspektifnya, bidang, tekstur, elemennya ataupun framing akan menjadi satu kesatuannnya dari gabungan sejumlah frame tersebut. Nilai keruangan akan terasa apabila karya ini tidak dilihat hanya dalam satu frame saja, melainkan dilihat keutuhan dari seluruh gabungan frame tersebut, itulah yang disebut mengkonstruksi bentuk ke dalam karya yang akan dihadirkan.

\section{Montase}

Karya nantinya juga menggunakan pendekatan dalam menyusun teknik montase dengan yang berarti satu karya terdiri dari puluhan bahkan ratusan imaji film negatif. Montase yang juga tidak umum disebabkan montase ini adalah menggabungkan sejumlah imaji yang bukan bagian dari bentuk aslinya dijadikan satu imaji baru, pengertian lain dari penggabungan sejumlah imaji juga diutarakan oleh Wells, Liz di bukunya Photograpy: A Critic Introduction.

\begin{abstract}
Photomontage: the use of two or more originals, perhaps also including written text, to make a combined imaji. A montased imaji may be imaginative, artistic, comic or deliberately satirical (Wells, 1997: 297)
\end{abstract}

Ada teknik lain dari penyususunan multi imaji dalam karya yang akan dibuat nanti yaitu disusun atau menggabungkan imaji berdasarkan urutan nomor film negatif yang tersedia dilembaran. Montase adalah sifat dari menggabungkan sejumlah imaji yang ingin disampaikan atau disusun, tidak ada metode khusus dalam penggabungannya, seperti yang juga diutarakan oleh Hirch dalam bukunya yang berjudul "Light and Lens: Photography in the Digital Age”.

\begin{abstract}
"Photomontage offers on opportunity to produce of astonisting juxtapossition and paradox, utilizing both manual and digital techniques. Consider exploring a theme, instead of single subject, in which the overall collection of images provides an extended and deeper examination of a topic. Keep in mind two-and three dimensional materials that can be incorporated into picture space through scanning" (Hirch, 2008: 207-208).
\end{abstract}

Dalam tahapan penyusunan ini digunakan teknik montase untuk mendapati susunan tentang bagaimana sketsa dibuat, sebagai panduan untuk pemotretan montase dan juga sebagai panduan penggabungan tersebut. Masalahnya lainnya adalah imaji tersusun tidak acak untuk membentuknya, melainkan butuh ketelitian dan hitungan seperti skema bentuk yang telah didesain. Dalam penyusunan digunakan kata sintetis yang berarti menggabungkan dua bentuk yang berbeda-beda untuk mendapat satu bentuk.

Karya yang akan dibuat nantinya hanya menggunakan media film negatif saja tanpa melalui proses cetak positif, yang berarti karya hadir seperti lembaran film negatif saja, hal ini membutuhkan ketelitian mengkonstruksi bentuk kedalammnya dan untuk melihat bentuk dalam representasinya. Akan ada tampilan baru kendati karya ini dilengkapi dengan penyinaran dibelakanngnya, keotentikan juga akan lebih menonjol disebabkan karya ini tidak dapat di re-produksi ulang atau dengan maksud memiliki salinannya (copy) keaslian dari karya ini hanya tunggal. Dalam masalah reproduksi karya seni sering kali karya 
yang dapat digandakan dapat mengurangi nilai ekonomis, bahkan bila digandakan nilai eksklusifitasnya berkurang senada dengan Benjamin bahwa karya seni hanya menggandakan agar mendapatkan kepalsuan dari hal yang asli, karena itu juga yang dilakukan oleh fotografi.

"The here and now of the original underlies the concept of its authenticity, and on the latter in turn is founded the idea of a tradition which has passed object down as the same, identical thing to the present day. For example, in photography it can bring out aspects of the original that are accessible only to the lens (which is adjustable and can easily change viewpoint) but not to the human eye; or it can use certain processes, such as enlargement or slow motion, to record imajis which escape natural optics altogether. This is the first reason. Second, technological reproduction can place the copy of the original in situations which the original itself cannot attain" (Benjamin, 2008: 21).

Film negatif merupakan media yang terbuat dari pita seluloid (plastik) transparan baik berwarna atau pun hitam putih, yang dilaburi sejenis campuran kimia peka pada salah satu permukaannya. Permukaan yang diberi lapisan kimia tersebut bisa disebut emulsi film, yang sangat peka terhadap sinar yang menyinarinya, dalam temperatur tertentu. Agar mendapatkan hasil dari negatif yang telah disinari, dibutuhkan pula proses kimiawi lainnya, bila film negatif warna membutuhkan proses type chemical 41 dan film negatif BW butuh proses kimiawi. Secara prinsip proses tersebut tetap sama dalam proses pengembangan emulsinya, yaitu membutuhkan bahan kimia yang telah dipersiapkan sesuai kadar kepekaan cahaya
ASA (American Standardization Association) dari film, dan bahannya antara lain adalah developer (pengembang), fixer(penetap) dan stopbath(penghenti). Setelah melakukan proses tersebut maka emulsi yang berada di seloid akan terlihat sesuai dengan apa yang yang diambil. Hal yang senada juga dituturkan oleh Turner bahwa negatif merupakan permukaan yang sudah dipersiapkan secara kimiawi, jadi bila terkena sinar maka permukaan akan merekam lalu diproses kembali secara kimiawi untuk menampilkan gambaran representasi imaji.

Pada dasarnya film negatif dibuat untuk menggandakan salinan objek yang terekam, melalui proses lainnya yaitu proses cetak positif. Karya akan dibuat nantinya akan menghadirkan karya yang dimulai dari bagaimana film negatif dijadikan sebagai media akhir.

\section{Fotografi Seni}

Menggunakan medium fotografi mencoba menemukan pendekatan teori yang sangat umum yaitu menurut Turner, Peter. Fotografi berasal dari bahasa Yunani = Phos, photos yang berarti sinar (light) dan grapho $=$ melukiskan (to describe). Seni atau proses untuk mendapatkan representasi yang akurat (benar dan tepat) dari objek, dengan menggunakan reaksi kimia antara sinar serta berbagai macam energi yang memancar, dengan permukaan yang sudah dipersiapkan secara kimiawi. (Peter, 1987:10).

Dalam membuat karya fotografi kali ini, menggunakan Negative Film sebagai media rekam dan kamera analog sebagai alat penangkap subjeknya. Film negatif merupakan salah satu yang mana di zaman kini sudah mulai dilupakan di zaman yang serba digital. Pengunaan film sebagai media menjadi salah satu cara untuk merepresentasikan fotografi, baik dimasa-masa film negatif masih digunakan sebagai media rekamnya, yang cukup memiliki nilai keontetikan yang khas. 
Film negatif merupakan media yang terbuat dari pita seluloid (plastik) transparan baik berwarna atau pun hitam putih, yang dilaburi sejenis campuran kimia peka pada salah satu permukaannya. Permukaan yang diberi lapisan kimia tersebut bisa disebut emulsi film, yang sangat peka terhadap sinar yang menyinarinya, dalam temperatur tertentu. Agar mendapatkan hasil dari negatif yang telah disinari, dibutuhkan pula proses kimiawi lainnya, bila film negatif warna membutuhkan proses type chemical 41 dan film negatif BW butuh proses kimiawi. Secara prinsip proses tersebut tetap sama dalam proses pengembangan emulsinya, yaitu membutuhkan bahan kimia yang telah dipersiapkan sesuai kadar kepekaan cahaya ASA (American Standardization Association) dari film, dan bahannya antar lain developer (pengembang) fixer(penetap) dan stopbath(penghenti). Setelah melakukan proses tersebut maka emulsi yang berada diseloid akan terlihat sesuai dengan apa yang yang diambil.

Dalam pencapainya karya fotografi kini telah memasuki zaman kontemporer, dimana fotografi sebagai media berekpresi dan berkomunikasi kepada siapa saja, baik ke sesama fotografer atau lingkungan masyarakat, bahkan fotografi telah menyamai dengan karya seni lainnya, seperti yang diungkapakan oleh Soedjono.

Fotografi seni menjadi salah satu media ekspresi yang dapat dibuat dengan berbagai konsep dan cara. Fotografi seni telah menjadi wahana untuk berolah rasa bagi fotografer yang ingin menoreh belang dan gading sebagai gaya pribadinya dalam dunia fotografi seni. Soedjono, (2007: 51)

Seni juga merupakan bangkitnya sebuah rasa emosi dengan meniru tragedi dan drama kehidupan manusia, karena hal itu dapat membersihkan emosi, dan membuatnya lebih dikendalikan (Sachari, Agus. 2002:21).

Berikut ini dipaparkan contoh-contoh karya terdahulu yang diciptakan melalui pemanfaatan film negatif

\section{David Hockney (1937)}

Hockney dilahirkan di Bradford, Britania Raya. Fokus bekerja sebagai seniman di Amerika Serikat. Ia cukup banyak melahirkan karya menarik dan ekperimental, baik di karya lukisannya ataupun karya fotonya. Banyak karyanya yang dikoleksi di Museum of Modern Art, New York's dan sejumlah galeri yang berada di Eropa. Karir melukisnya digeluti ketika mengikuti studi di Royal Colege of Art, London (195962) dan penampilan pertamanya dibuktikan dengan berpameran tunggal di Kasmin Galery, London (1963). Sepak terjangnya di dunia visual art tidak diragukan lagi, bahkan banyak buku seni mencatatnya sebagai Pop Artistyang sangat diperhitungkan. Karya fotografinya yang cukup membuat heboh yaitu karya kolase menggunakan print Polaroid yang berupa susunan bagian-bagian yang telah difotonya dengan menggunakan kamera Polaroid. Objek seakan-akan presisi dan dinamis, dan seni kolase diperkenalkan Hockney menggunakan cetak polaroidnya.

Terlihat di gambar sebuah foto kolam renang (lihat gambar 2), seperti terpotongpotong menjadi beberapa bagian, setiap bagian

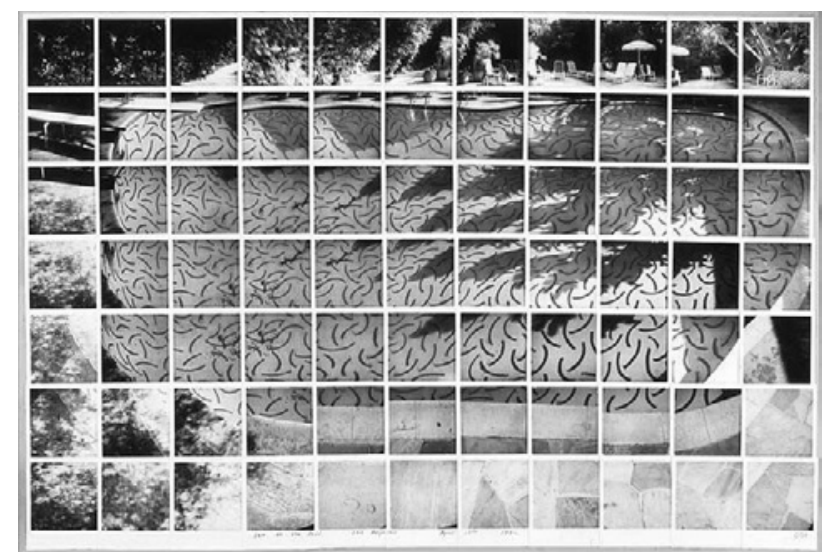

Gambar 2. Sun On The Pool-1982.

(Sumber: http://www.hockneypictures.com/photos/photos polaroid_05.diakses pada tanggal 8 September2017, 14:30 wib). 
tersebut menyatukan antara frame satu dengan frame berikutnya. Susunan ini tidak dapat begitu saja tersusun dengan baik apabila perhitungan dan perkiraan sudut bidang atau bentuk yang diinginkan tidak diperhatikan oleh fotografernya. Hockney ingin melihat struktur bidang yang berada dikolam, yang mana subjek foto Hockneykolam renang yang memiliki air jernih kebiruan, sehingga warna yang terpancar dari foto tersebut, memiliki warna dominan dan warna lainya yang berada di sekitar kolam (atau lantai kolam) seperti membuat sebuah frame baru. Terdapat hal yang cukup unik, David memainkan perspektif menggunakan kolase cetak Polaroidnya, yang terhitung sekitar 77 frame. Polaroid dari susunan vertikal 7 dan horizontal 11, kombinasi dari gabungan setiap frame ini cukup sulit apabila salah perhitungan, yang berarti frame akan diulang lagi. Dalam hal melihat karya ini bisa diperhatikan bahwa perpektif penonton sedang dimainkan oleh karya foto ini, lebih-lebih penyambung antar setiap frame memiliki garis putih pembatas, seperti melihat suatu bangunan atau bentuk yang dipotong-potong lalu dikembalikan lagi seperti aslinya kendati tidak tampak seperti aslinya.

\section{Thomas Kellner (1966)}

Kellner lahir di Siegen, German. Tahun 1996 ia berhasil meyelesaikan studinya di Universitas Siegen Jurusan Seni dan Sosiologi. Dimulai pada tahun 1986 ia fokus menggunakan fotografi sebagai sarana mengungkapkan konsep dan sejumlah ekperimen yang iia kerjakan. Kellner adalah peraih penghargaan Kodak Germany award sebagai seniman visual profesional muda. Kini hidupnya dihabiskan untuk menggunakan foto dengan berkeliling di sejumlah belahan dunia, Eropa, Amerika, Asia. Hingga kini ia masih aktif megikuti sejumlah proyek pribadi, pameran tunggal atau kolektif dan sering diundang sebagai kurator pameran fotografi di Eropa.

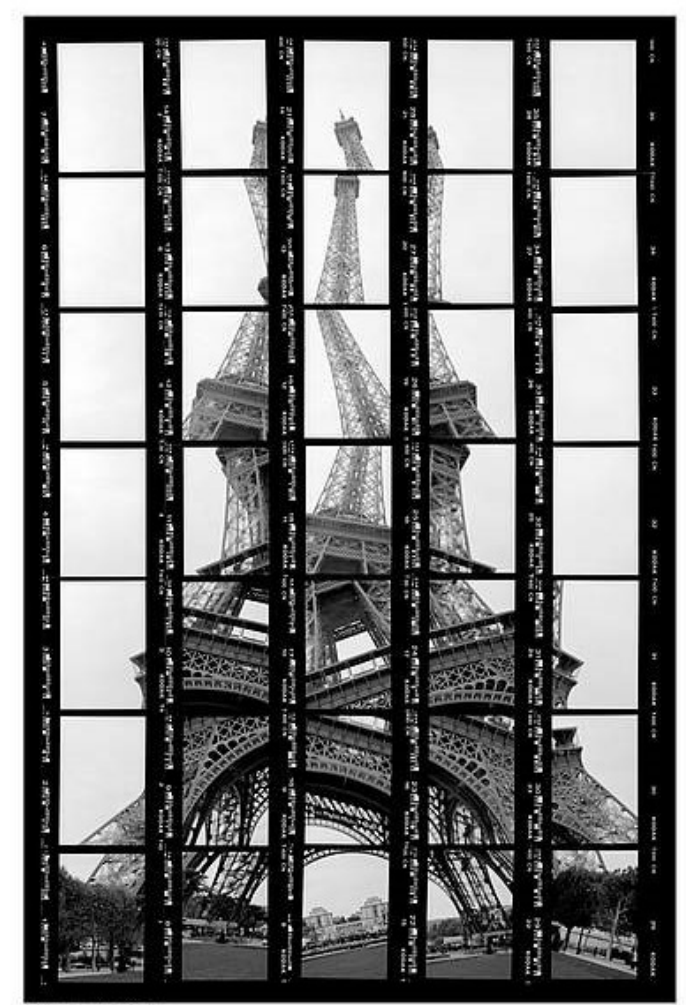

Gambar 3. Paris, Tour Eiffel, 1997, BW-Print on paper $17,5 \times 27,0 \mathrm{~cm}$.

(Sumber: http://www.thomaskellner.com/artworks/portfolios/ black-white/. Sebuah bangunan menara Eiffel (Paris)).

Kellner berfokus pada bangunan ikonik negara tertentu, akan tetapi konstruksi tidak ditambahkan lagi melainkan hanya mengeser bagian-bagian tertentu dari sudut pengambilan sehinga bangunan tersebut terdapat "gangguan" estetis, tidak mengurangi sisi fotografinya. Kellner tetap bersikukuh menggunakan teknik cetak contact print, sebagai sarana media artistiknya dan ungkapanya terhadap fotografi kini.

Gambar tersebut dikonstruksi ulang menggunakan pengambilan berurutan pada roll film negatif hitam-putih (lihat gambar3), antara frame di sisi lain terlihat tidak presisi. Antara frame tidak terjadi penyatuan presisi sehingga menghasilkan bentuk yang rusak. Cara Kellner memperlihatkan tekniknya tergolong unik dan penuh perhitungan, setiap frame diperhatikan sebagai satu kesatuan yang utuh, maka bisa dipastikan bila frame lainnya salah berarti pengunaan roll film bisa tidak berarti apa-apa alias gagal. Diketahui 


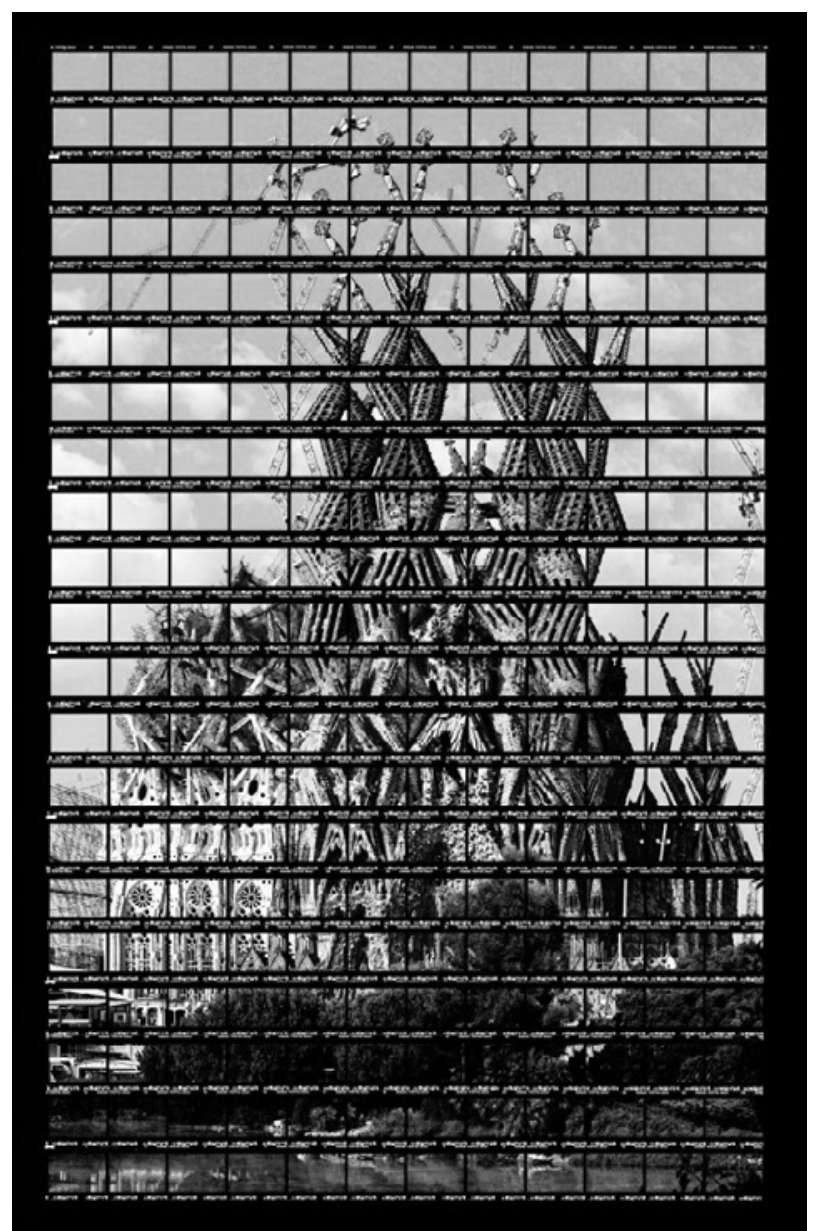

Gambar 4. (C) Thomas Kellner. La Sagrada Familia, 2003. 28 x 18 inches. Chromogenic Color Print, Courtesy of Cohen Amador Gallery, New York.

(Sumber: Hirch, R. 2008:207)

bahwa ini merupakan karya pertama Kellner pada tahun 1997, ia masih menggunakan satu roll film dalam menyusun gambarnya, teknik menyusun dipastikan penuh dengan perhitungan. Kejujurannya dalam menggunakan teknik cetak contact print tidak bisa ditipu. Pun ketika karya sudah jadi, maka urutan film negatif akan memperlihatkan urutan yang sesungguhnya dari nomer yang ada di setiap film negatif yang ia pakai. Kellner tampaknya memainkan peran, mendapatkan kerumitan dalam pemotretannya, ditempuhnya untuk mendapatkan originalitas berkarya.

Gambar di atas menampilkan karya Kellner, yang diambil di London yaitu sebuah bagunan The Lincoln Memorial, La Sagrada Familia pada tahun 2003. Pola Kellner dalam mendkonstruksi bangunan ikonik, antara teknik tahun 1997 masih dipertahankannya. Salah satu perbandingan dengan karya yang hadir tahun 2003 tak jauh ada perubahan, akan tetapi keseriusannya mulai memuncak. Ketika ia tidak lagi menggunakan 1 roll seperti karya pertamanya, dia sudah mulai lebih fokus dengan mengambil objek arsitektur atau bangunan menggunakan lebih dari satu roll. Karya tersebut memiliki frame, terhitung 252 frame yang berarti urutan tersebut menggunakan sekitar 7 roll fim negatif dengan ukuran kertas cetak $28 \mathrm{x}$ 18 inc converter $71 \times 45 \mathrm{~cm}$. Angka frame terbukti bahwa apa yang dilakukannya atau pencapainya yang bisa dikatakan lebih serius, dan sungguh-sungguh, ini disebabkan ia baru bisa mengetahui bahwa benar atau salahnya pemotretannya tidak bisa di saksikan langsung, melainkan di film harus dicuci dahulu dan disusun baru hal yang demikian bisa diketahuinya. Cara memotret yang butuh perhitungan ini, tidak bisa dilakukan bila dia hanya mengandalkan ingatan saja, akan tetapi sketsa diperlukan untuk menentukan setiap frame antara frame berikutnya.

\section{METODE, IDE, DAN EKPLORASI}

\section{Pembentukan Ide}

Karya fotografi yang dihadirkan merupakan salah satu pencapai untuk memanfaatkan teknologi yang sudah ditinggalkan, dengan memanfaatan media analog sebagai salah satu alternatif baru yang ditawarkan dalam riset penciptaan ini. Yaitu dengan menghadirkan kembali media film negatif sebagai sarana media akhir tanpa melalui proses cetak positif. Butuh penanganan khusus dalam membuat karya ini, artinya akan ada usaha-usaha menembus batas dari kebiasaan umum yang dikerjakan oleh sebahagian fotografer atau menawarkan kemungkinan baru seperti perwujudanya. Usaha ini menjadikannya suatu mentode yang unik dalam penciptaan fotografi ditengah era teknologi digital.

Tidak hanya sekedar menggunakan media film negatif saja, melainkan memuat 
puluhan bahkan ratusan lembaran film negatif saling terhubung secara sintetis. Karya montase ini disusun secara berurutan berdasarkan nomor yang tersedia pada media film negatif (1-36), ini merupakan salah satu upaya menghubungan antara peran kreasi, konstuksi dan ketelitian. Karya ini akan terdiri dari ratusan lembaran film negatif color $35 \mathrm{~mm}$, yang telah diproses secara kimiawi dimesin Chemical type 41 (C41). Ratusan frame tersebut menghadirkan suatu kreasi konstruksi bentuk dengan teknik montase sintetis. Sintetis dengan maksud adalah menyambung antar frame satu dengan frame lainnya, sehingga membentuk satu kesatuan yang utuh berdasarkan urutan nomer-nomer yang tersedia di film negatif dari objek yang berbeda-beda.

\section{Pengelolaan Ide Penciptaan}

Dalam mengetengahkan karya seni dari media fotografi menggunakan teknik tersebut, akan memberikan pengertian tentang seni yang ingin diungkapkan secara luas, dengan merespon hal-hal yang bersifat ilusi. Merespon kembali peristiwa lewat wacana estetika yang lebih terbuka kendati belum menyelesaikan masalah yang ada disekitar produksi dan konsumsi karya. Seperti sebuah bangunan, mencoba mengambil peran untuk membangun sebuah imaji ilusi ke dalam karya fotografi, menggunakan susunan bentuk satu, dari berbagai macam objek yang dihadirkan secara berurutan, sehingga menghasilkan atau terlihat seperti sebuah bentuk yang dikenali atau sangat menyerupai bentuk-bentuk baru, apakah itu dilihat dari pencahayaannya, perspektifnya, bidang, tekstur, elemennya ataupun framing akan menjadi satu kesatuannnya dari gabungan sejumlah frame tersebut. Maka akan terasa nilai keruangan apabila karya ini tidak dilihat hanya satu frame saja, melainkan dilihat keutuhan dari seluruh gabungan frame tersebut, itulah yang disebut mengkonstuksi bentuk dalam karya yang akan dihadirkan nanti.

Seperti tampil di karya dari ratusan lembaran film negatif yang telah disusun dengan mengkonstruksi bentuk dari frame-frame yang saling berhubungan akan menghadirkan bentuk-bentuk yang mudah dikenali kendati ukuran telah diperbesaran disebabkan jumlah film negatif. Bentuk yang dimaksud bentuk perseptual yaitu bentuk yang dipengaruhi hal yang sangat melatar belakanginya atau telah dikenal, apakah itu dari penglihatannya dan persepsinya. Bentuk perseptual merupakan hasil dari saling mempengaruhinya antara obyek fisik, pencahayaan dan kondisi yang berlaku dari sitem syaraf penglihatan. Demikian juga setiap pengalaman visual melekat dalam konteks ruang dan waktu. Seperti tampilan objek dipengaruhi oleh objek lainnya yang berada dalam ruangan yang sama dalam ruang, dan juga tidak terlepas dari saling pengaruh oleh pandangan terdahulunya, (Embun, 2009:98).

Contoh bentuk dalam karya:

Karya ini (lihat gambar 5) akan membuktikan bahwa ada awalan dan akhiran dalam proses penciptaannya tersebut, merupakan pencapaian proses kreatif yang tidak datang begitu saja, maka dibutuhkan hal lain dalam uraiannya.

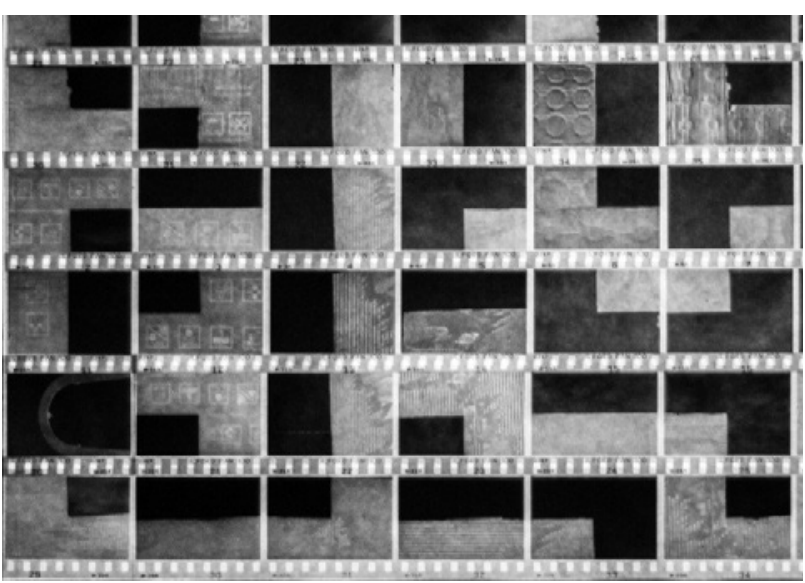

Gambar 5. Sumber: Dokumen Pribadi dan Katalog pameran Katalog Pameran: Seni Media Rekam "Jalam Menuju Kreatifitas International \#9" Jogja Galeri, 2017. 


\section{Film Negatif sebagai Media Akhir}

Film negatif merupakan salah satu media yang dapat merekam objek didalamnya disebabkan permukaannnya telah dipersiapkan campuran kimiawi dalam proses perekaman juga dibutuhkan kamera yang berjenis kamera SLR (Single Lensa Reflex) analog/manual. Kini di era yang serba digital pemanfaatan media film negatif kurang mendapatkan tempatnya sebagai media rekam penangkap objek, kebanyakan sudah beralih ke media digital. Menjadi pokok permasalahan yang cukup menarik, dalam proyek penciptaan karya ini untuk menempatkan posisi karya. Apakah disebabkan media itu sendiri, atau proses produksi di dalamnya seperti perwujudan penggabungan bentuk dari ratusan frame dan ratusan objek yang juga berbeda tersebut.

Pengunaan Film negatif memiliki nilai yang otentik, keontetikan, bisa berarti karya tidak akan memiliki salinan seperti cetakan yang bisa direproduksi (digandakan). Seperti umumnya karya-karya fotografi yang dapat direproduksi ulang, di produksi cetakannya dan diperbanyak dan mungkin nilai juga akan berbeda dengan apa yang dihadirkan melalui karya ini. Karya ini tidak membuka celah untuk diperbanyak atau memiliki salinannya, bisa juga diartikan sebagai keotentetikan khusus yang melekat di media itu sendiri. Ketika karya ini telah diproduksi maka karya ini seperti terlihat seperti lukisan di seni rupa yang tidak memiliki salinan, hal ini sangat bertolak belakang apa yang dikerjaan oleh prakstisi fotografi.

Film negatif merupakan media yang terbuat dari pita celuloid (plastik) transparan, baik berwarna atau pun film hitam putih. Permukaan yang telah diberi lapisan kimia tersebut bisa disebut emulsi film, yang sangat peka terhadap sinar yang menyinarinya, dalam temperatur tertentu. Agar mendapatkan hasil dari negatif yang telah disinari, dibutuhkan pula proses kimiawi lainnya seperti proses type chemical 41.
Secara prinsip dalam proses tersebut perihal proses pengembangan emulsinya tetap sama, yaitu membutuhkan bahan kimia yang telah dipersiapkan sesuai kadar kepekaan cahaya dari film, dan bahannya antar lain develover (pengembang) fixer(penetap) dan stopbath(penghenti). Setelah melakukan proses tersebut maka citra emulsi yang berada diseloid akan terlihat sesuai dengan apa yang terekam. Citra emulsi ini lah yang nantinya menjadi akhir dari karya hanya dapat dilihat menggunakan bantuan cahaya tambahan dibelakang film negatif dan jadi akhir pada karya ini, hal tersebut akan dijelaskan dalam uraian bab ini.

Dalam mewujudkannya juga memiliki tahapan yang perlu diperhatikan sebagai bagian yang tidak terpisahkan, agar perwujudannya baik dan sesuai maka dari itu metode penciptaan ini menguraikan sejumlah cara yaitu: (1) Pencatatan isu-isu sebagai bentuk.Karya seni fotografi sangat membutuhkan catatan, catatan sangat penting terbentuknya langkah yang diinginkan dalam produksi. Catatan yang dimaksud bisa berupa tulisan atau yang sudah berupa berupa sketsa. Catatan menjadi peran yang sangat penting dalam terwujudnya karya, catatan tersebut kembali dibuka seiring pembuatan lanjutan yaitu sketsa, apakah itu cocok atau tidak untuk dihadirkan, masih dalam pertimbangan atau perlu penyaringan lagi. Kecocokan tersebut sangat berkaitan dengan penyusunan bentuk atau objek yang akan dihadirkan, tidak tutup kemungkinan catatan tersebut hanya diambil yang memungkinkan saja. Biasanya catatan tersebut hanya menggambarkan tulisan teksteks seperti yang akan dikonstruksikan.

Cara yang kedua (2) yaitu menggunakan sketsa sebagai catatan. Fotografi pada umumnya menangkap moment yang atau rekaman yang direkayasa, tapi tidak semua fotografer menggunakan sketsa sebagai penuntut pemotretan, itu juga bergantung pada apa yang akan dihadirkan 
fotografer tersebut atau objek apa yang direkam. Sketsa pada umumnya digunakan sebagai dasar untuk mengambar atau melukis dari sketsa tersebut si seniman membuat kembali garis tegas menggunakan cat atau element pendukung untuk menghasilkan karya seninya.

Sketsa yang dimaksud bukan seperti yang diuraikan di atas, melainkan sketsa dibuat sebagai langkah-langkah atau panduan pemotretan, maka dari itu sketsa sangat dibutuhkan. Urutan demi urutan nomer ini juga menuntut perekaman objek yang tersedia di model sketsa, yang antara kotak/frame saling berkaitan menjadi satu kesatuan utuh. Tanpa menggunakan sketsa yang dimaksud, maka mustahil bentukan tercapai, disebabkan bila hanya mengandalkan ingatan saja, hal itu juga sangat mustahil.

Sistem perhitungan dan ketepatan dalam menentukan eksposur untuk membuat karya ini sangat perlu diperhatikan, baik dalam pemotretan ataupun dalam penyusunan film negatif nantinya. Apabila salah dalam mengurutkan frame dalam pemotretan maka bisa dipastikan karya secara keseluruhan akan gagal maka diperlukan roll film negatif baru (dimulai dari awal). Bisa juga diartikan, satu frame salah dalam pemotretan ini, maka bisa dipastikan susunan urutannya yang lain akan berantakan atau gagal.

Dibutuhkan sketsa untuk panduan pemotretan, tapi sketsa juga tidak banyak membantu bila urutan objek yang telah difoto tidak ditandai, produski karya ini rawan dalam kesalahan, penandaan sketsa juga hal yang sangat terpenting, agar antara objek-objeknya tidak tercampur dan dapat dipisahkan.

Dasar pertama untuk mendapatkan sketsa dibutuhkan juga satu perkiraan objek apa yang akan dihadirkan yang bisa dijangkau atau berkesesuaian, artinya objek yang terjangkau, imajinasi yang liar tapi tidak ditopang dengan keberadaan objeknya, itu sama saja kesulitan yang cukup nyata.

Contoh Model Sketsa: (gambar 6)

Keterangan Sketsa:

Dalam menghadirkan bentuk yang telah dikonstruksi di dalam sketsa, juga dibutuhkan pemisahan sketsa agar bagian objek yang akan direkam diketahui dengan baik dengan dilengkapai keterangan objek didalamnnya. Fungsinya lain dari Sketsa:

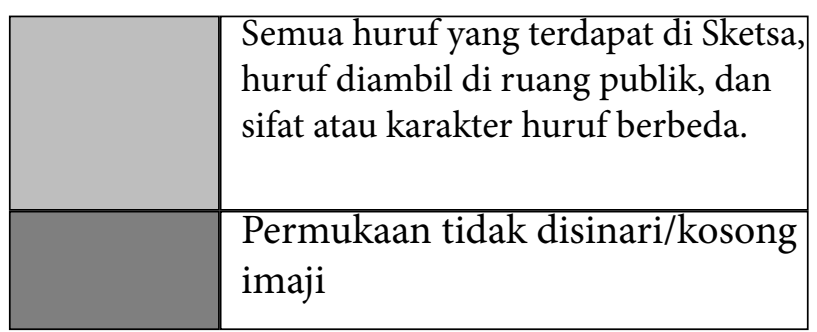

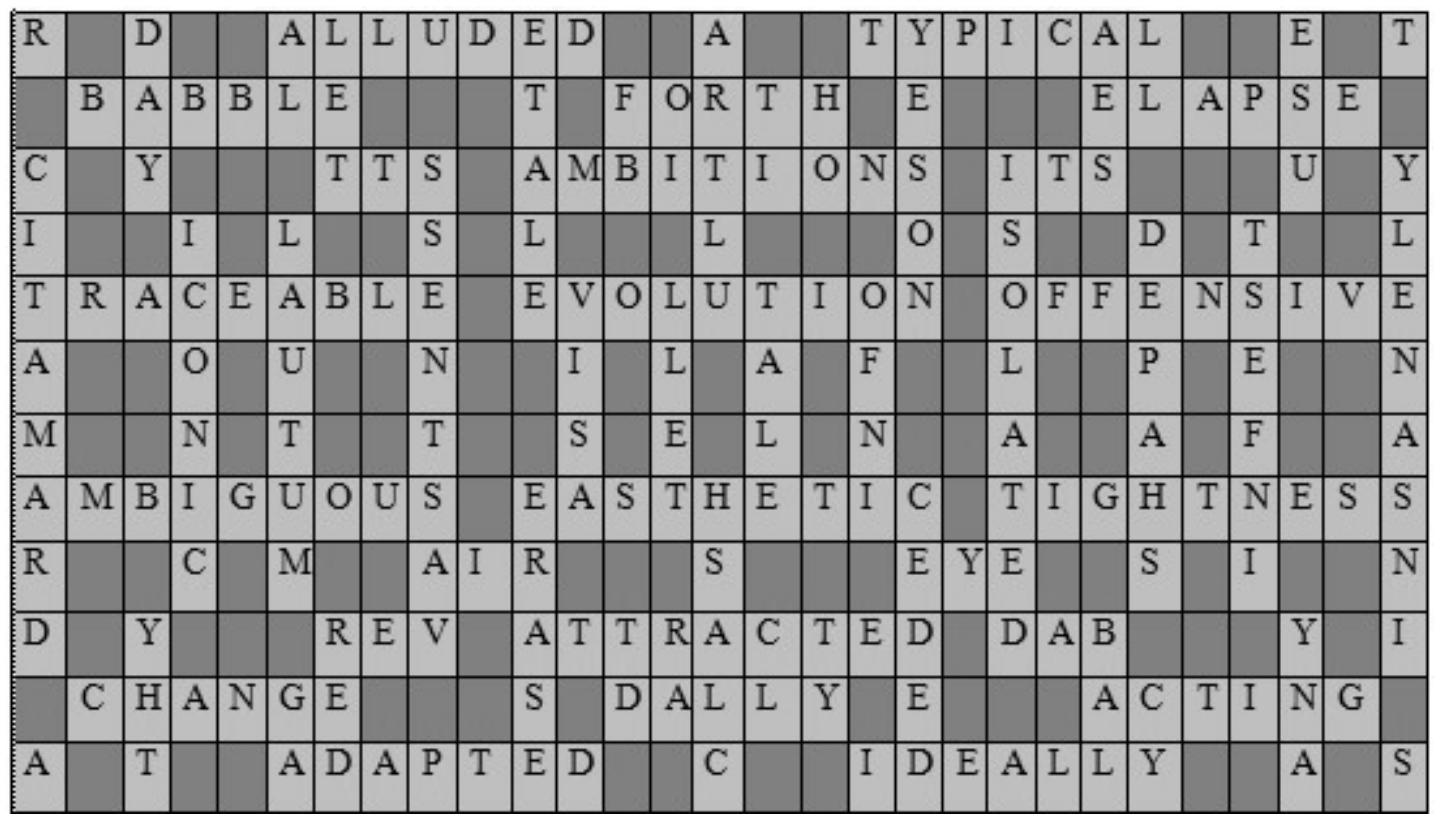

Gambar 6. Rancangan penyusunan film negatif 
a. Sketsa merupakan arsip dalam setiap produksi karya.

b. Sketsa dibuat untuk menuntun pengambilan objek atau perekaman.

c. Menghadirkan elemen penting di sketsa sebagai penanda, objek apa dan warna apa, hal itu akan membantu wujud karya secara utuh akan terlihat atau tergambar.

d. Sketsa juga dibutuhkan kembali apabila perekaman objek telah dilakukan sebagai penuntun penyusunan lembaran film negatif diatas medium transparan, seperti Kaca bening, atau resin bening.

e. Sketsa juga dapat menuntun atau mengetahui ukuran media transparan tambahan diketahui dari jumlah kotakkotak yang tersedia.

\section{PEMBAHASAN}

Pemotretan dilakukan menggunakan kamera analog FM 2 dan F65 dan film negatif berukuran $35 \mathrm{~mm}$, untuk mendapatkan 1 karya, membutuhkan lebih dari satu roll fim hingga 10 roll film, masing roll film menyediakan 36 frame.

Pengambilan objek yang berdasarkan sketsa bisa berupa objek yang terdapat di sekitar kita (public space), manusia, teks dan benda yang sangat berhubungan dengan konstuksi yang dimaksud, atau bisa juga objek buatan hanya berupa plat datar, seperti kertas atau karton yang telah dipersiapkan.

Proses cuci negatif dilakukan di salah satu studio komersil dengan mengandalkan tenaga atau bantuan orang lain dalam melakukan proses cuci negatif C41.

Karya ini akan disusun di atas plat transparan secara montase, dan karya ini belum dapat dinikmati seperti melihat karya seni pada umumnya, apabila tidak dilengkapi cahaya di belakangnya.

Cahaya memiliki peran yang sangat penting dikarya ini (lihat gambar 7). Seperti kita melihat film negatif yang telah diproses secara kimiawi C41, melihatnya harus diarahkan ke sumber cahaya, maka emulsi dan imaji gambar di dalam film negatif yang telah direkam akan terlihat jelas. Ini merupakan sesuatu kegiatan dari ingatan saat ingin melihat film negatif. Pengunaan lampu LED salah satu alasannya adalah disebabkan cahaya ini tidak mengeluarkan panas yang tinggi atau tidak terlalu panas yang dapat merusak seluloid, ketimbang menggunakan cahaya lampu pijar atau lampu neon. Suhu yang panas adalah musuh utama. Suhu yang panas lebih dari 60C dapat merusak permukaan seluloid film negatif bahkan dapat meleleh, untuk menghindari hal tersebut terjadi maka digunakan penyinaran yang tidak terlalu panas kendati dihidupkan dalam kurun waktu yang cukup lama.

Agar penyinaran dapat merata, jarak jatuh cahaya juga harus diatur, dan agar bintik/titik cahaya tidak terlihat maka dipasang dibagian belakang (gambar 8) negative film sejenis mika berwarna putih susu yang bertujuan dapat menghambat

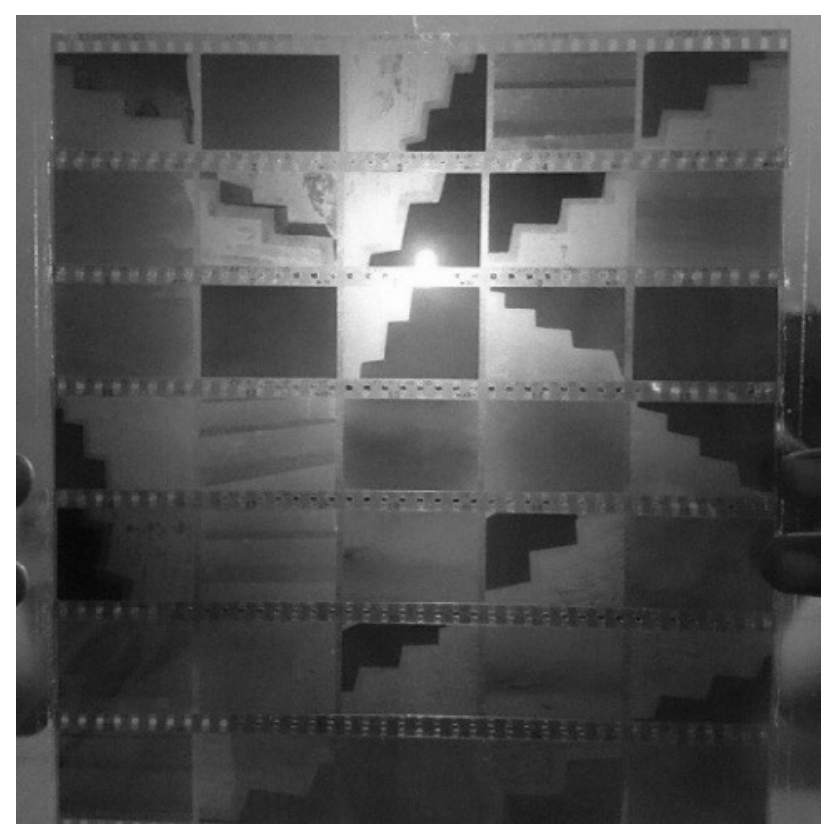

Gambar 7. Lembaran Film negatif disusun diatas permukaan transparan seperti kaca bening, resin bening. 
cahaya tidak terlalu panas dan cahaya menjadi rata.

\section{SIMPULAN}

Karya yang dihadirkan, nantinya

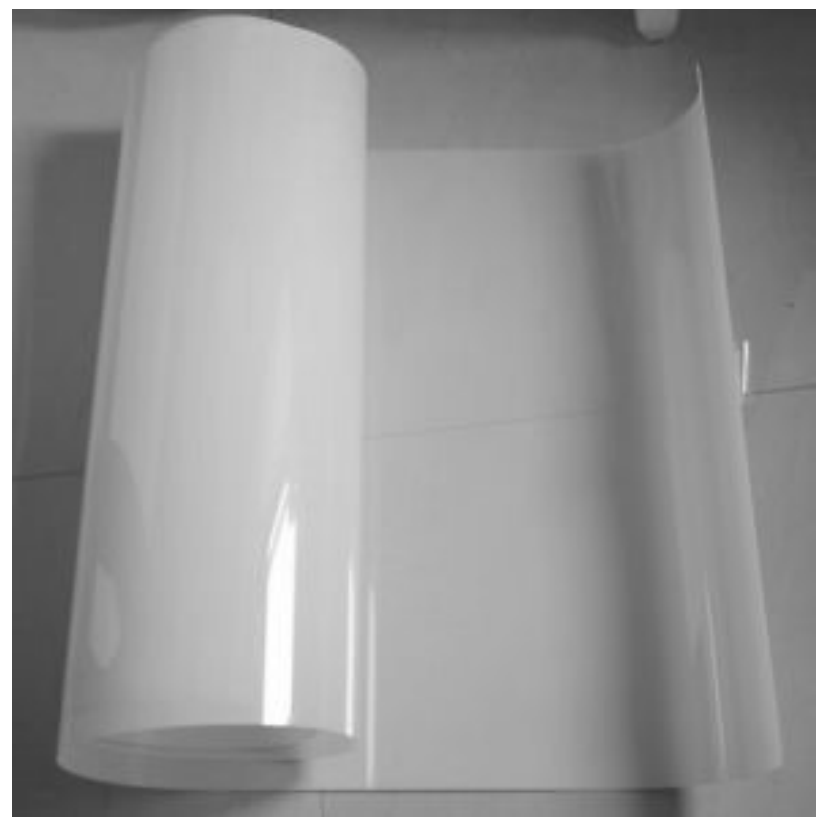

Gambar 8. Lembaran mika berwarna putih susu sebagai lapisan pada lembaran film negatif sebelum terkena cahaya. (Sumber: Dokumen Pribadi)

\section{CONTOH KARYA}

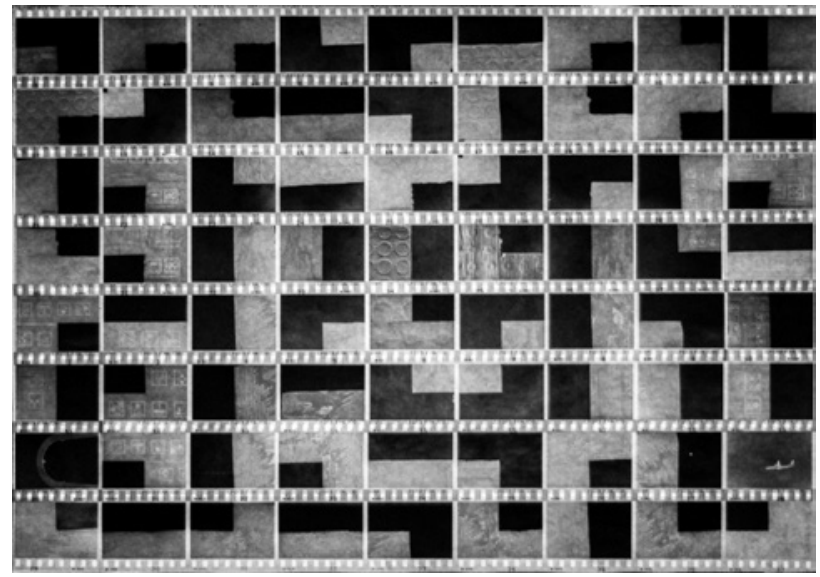

Gambar 9. "Labirin \#1", 33.75 x 28 cm, LED Box, Film negatif Shets on Glass (2016)

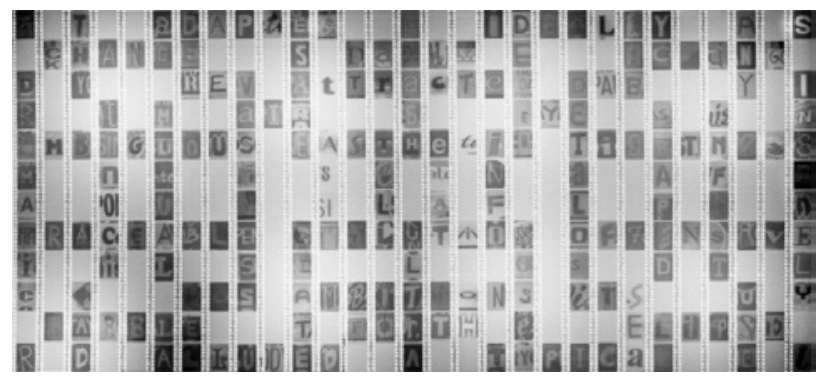

Gambar 10. “ANAGRAM No 214 \#2”, 120 x 68 cm, LED Box, Film negatif Shets on Glass (2017) akan menjadi salah satu sistem dalam mewujudkan kekaryaan di bidang fotografi, dengan menggunakan metode konstuksi dan montase dari sejumlah urutan imaji film negatif dan akan mendapatkan representasi baru. Akan terbentuk juga konsep presentasi yang unik melalui bahasa visual fotografi, dengan pendekatan komunikasi kepada pencinta seni khususnya. Akan tercipta juga ruang evaluatif dalam perjalanan proses kreatif kreator, baik sebagai fotografer ataupun sebagai akademisi.

Adanya sebuah presentasi intelektual dalam perkembangan kekakaryaan seni dan dalam pengayaan wacana seni serta membangkitkan kesadaran yang cukup kritis dalam masyarakat di Indonesia, pentingnya proses kreatif dalam berkesenian. Salah satu bentuk pertanggung jawabab penulis dalam berkarya seni terhadap konsep-konsep yang diusung, sebagai sarana intelektual membuktikan bahwasanya melalui karya yang akan dihadirkan nanti akan menjaga keotentikan karya karena masih menggunakan film negatif.

\section{KEPUSTAKAAN}

\section{Buku}

Amir P, Yasraf. "Hiper Semiotika-Tafsir Cultur Studies Atas Matinya Makna" Yogyakarta, Jalasutra. NY

Arnheim, Rudolf. "Art and Visual perseption, A Psychology of the Creative Eye" the new Version, University of California Press. 1974,

Bonhan C.C and David Hodge, "The Contemporary Art Book, London, Carlton 20 Mortimer Street. 2009

Clarke, Graham, "The Photography" Oxford University Press, New York. 1997.

Feldman, Edmund Burke, Art as Imaji and Idea, New Jersey, The Universit of Gerorgia. 1967,

Hedgecoe's, John. "New Introductory Photography Course". USA: Focal Press. 1996. 
Heiferman, Marvin. "Photography Changes Everthing". New York, Aperture Foundation. 2012.

Hirch, Robert. "Light and Lens: Photography in the Digital Age". USA: Focal Press. 2008

Kenyowati, Embun. Disertasi ; ilusi dalam seni visual, FIB UI, Jakarta. 2009.

Langford, Michael. "The Spesial Efects Photograhy". London: Ebury Press, National Magazine House. 1981

Markowski, Gene. "The Art of Photography:Imaji and Illusion", University of Virginia, New Jersey. 1984,

Simon Alexander, Grier Cooper, Tom Hauck, Bill Diller, . "The Daily Book of Photography 365 Readings that Teach, Inspire \& Entertain", USA, Walter Foster. 2010.

Soedjono, Seoprapto. "Post-Pourri Fotografi". Jakarta, Universitas Trisakti. 2006.

Turner, Peter, History of Photography. New York: Exeter Books. A Bison Book. 1987.

Wells, Liz., "Photography: A Critic Introduction" London \& New York, Routledge. 1997

\section{Pustaka Laman}

http://www.hockneypictures.com/photos / photos_polaroid_05. diakses pada tanggal 18 oktober 2016, pukul 14:30 wib.

http: / / www.thomaskellner.com / artworks/portfolios/black-white/, di akses pada tanggal 20 oktober 2016 , pukul 12.30 wib.

http: / / www.thomaskellner.com / typo3temp/pics / 1e4fad28ee.jpg, di akses pada tanggal 20 Oktober 2016, pukul 12.30 wib

https://www.magnumphotos.com/theoryand-practice/magnum-contactsheets/di akses pada tanggal 25 November 2016, pukul 17.00 wib.

https:// www.martinwilson.comdi akses pada tanggal 19 Maret 2017, pukul 16.00 wib

\section{Katalog Pameran}

Katalog Pameran: Seni Media Rekam "Jalam Menuju Kreatifitas International \#9" Jogja Galeri, 2017. 